\title{
Urgensi Pembaharuan Undang-Undang Perlindungan Konsumen Indonesia Di Era E-Commerce
}

\author{
Abdurrahman Mazli \\ Magister Hukum Universitas Islam Indonesia Yogyakarta Indonesia \\ Jln. Cik Di Tiro No.1, Yogyakarta, Indonesia, 55223 \\ mazliabdurrahman@gmail.com
}

\begin{abstract}
This article discusses the urgency of renewing Indonesia's consumer protection law in the ecommerce era. The formulation of the problem is the urgency of renewing Indonesian consumer protection laws in the e-commerce era. The method used is normative legal research, where the author analyzed legal concepts and regulations related to consumer protection in Indonesia as well as books, journals and other documents needed in conducting research. The results of this study conclude that consumers in the modern era are in a weak position and legal problems are found in the practice of buying and selling e-commerce, while the current consumer protection law is inadequate to solve the problems that arise, so that Indonesia's consumer protection law is urgently needed to be updated.
\end{abstract}

Key Words: Consumer protection; e-commerce; Indonesia

\begin{abstract}
Abstrak
Artikel ini membahas tentang urgensi pembaharuan undang-undang perlindungan konsumen Indonesia di era e-commerce. Rumusan masalahnya bagaimana urgensi pembaharuan hukum perlindungan konsumen Indonesia di era e-commerce? Metode yang digunakan adalah penelitian hukum normatif yaitu penulis menganalisis konsep-konsep dan peraturan hukum yang berkaitan dengan perlindungan konsumen di Indonesia serta juga menganalisis buku-buku, jurnal-jurnal dan dokumen-dokumen lain yang dibutuhkan dalam melakukan penelitian. Hasil penelitian ini menyimpulkan bahwa konsumen di era modern berada dalam posisi yang lemah serta ditemukan permasalahan-permasalahan hukum dalam praktik jual beli secara e-commerce, sedangkan undangundang perlindungan konsumen yang berlaku sekarang tidak memadai untuk menyelesaikan permasalahan-permasalahan yang muncul tersebut, sehingga undang-undang perlindungan konsumen Indonesia menjadi urgen untuk diperbaharui.
\end{abstract}

Kata-kata Kunci: Perlindungan konsumen; e-commerce; Indonesia 


\section{Pendahuluan}

Saat ini kompleksnya hubungan atau transaksi perdagangan disebabkan oleh adanya jasa teknologi, khususnya teknologi informasi. Akibatnya transaksitransaksi dagang semakin berlangsung dengan cepat dan tampak dengan lahirnya transaksi-transaksi yang disebut dengan e-commerce. ${ }^{1}$ Arus globalisasi dan perdagangan bebas serta kemajuan teknologi, telekomunikasi, dan informasi telah memperluas ruang transaksi barang dan jasa yang ditawarkan menjadi lebih bervariasi, baik barang dan jasa produksi dalam negeri maupun produksi luar negeri. Kemajuan tersebut telah menghadirkan banyaknya fasilitas telekomunikasi dan canggihnya produk teknologi informasi yang mampu mengintegrasikan semua media informasi untuk mempermudah segala kegiatan manusia sehari-hari yang membuat dunia semakin mengecil (shrinking the world) sekaligus memudarkan batas negara. ${ }^{2}$

Kegiatan bisnis mendominasi berbagai aktivitas manusia dewasa ini. Kegiatan bisnis dilakukan manusia di desa-kota-dunia, anak-dewasa, miskinkaya, pendidikan rendah-tinggi, formal-informal, yang kesemuanya bertujuan untuk mencari keuntungan yang tidak ada lain diperoleh dari hasil penjualan barang/jasa. Di dalam transaksi jual-beli barang dan jasa setidak-tidaknya terdapat dua pihak yang saling berhubungan, yaitu: pertama, pihak penyedia barang atau penyelenggara jasa, kedua, pihak pemakai/pengguna barang atau jasa tersebut.

Dalam literatur ekonomi, kelompok pertama disebut sebagai pengusaha atau pelaku usaha, sedangkan kelompok kedua disebut sebagai konsumen. Setiap manusia adalah konsumen. Semua pelaku usaha adalah konsumen, sebaliknya tidak semua konsumen adalah pelaku usaha, sehingga masalah-masalah yang dihadapi oleh konsumen adalah menyangkut semua lapisan dan golongan masyarakat yang perlu mendapatkan perhatian. ${ }^{3}$

Dunia perdagangan saat ini, perlindungan konsumen harus dibangun untuk menghadapi kemjauan yang terjadi. ${ }^{4}$ Transaksi elektronik adalah suatu hal yang tidak dapat dihindarkan. Electronic Commerce (e-commerce) adalah suatu contoh dari kemajuan yang terjadi, dimana transaksi bisnis tidak lagi dilakukan secara

${ }^{1}$ Huala Adolf, Hukum Perdagangan Internasional, PT. Raja Grafindo Persada, Jakarta, 2005, hlm. 1.

2 Arsyad Sanusi,, "Efektivitas UU ITE dalam Pengaturan Perdagangan Elektronik (E-Commerce)”, Jurnal Hukum Bisnis, 29 (1), 2010, hlm. 5.

3 Shidarta, Hukum Perlindungan Konsumen, PT Grasindo, Jakarta, 2000, hlm. 148.

${ }^{4}$ Michael S. Barr and Reuven S. Avi-Yonah, "Globalization, Law and Development", Michigan Journal of International Law, Vol. 26:1, University of Michigan Law School, 2004, hlm. 11. 
konvensional, yang mengharuskan pembeli berinteraksi langsung dengan penjual atau adanya keharusan menggunakan uang tunai. ${ }^{5}$

Kehadiran e-commerce memberikan kemanjaan yang luar biasa kepada konsumen karena konsumen tidak perlu ke luar rumah untuk berbelanja. Di samping itu pilihan barang/jasapun beragam dengan harga yang beragam pula. Hal ini menjadi tantangan yang positif dan sekaligus negatif. Hal ini dapat dikatakan positif karena kondisi tersebut dapat memberikan manfaat bagi konsumen untuk memilih secara bebas barang/jasa yang diinginkannya. Konsumen memiliki kebebasan untuk menentukan jenis dan kualitas barang/jasa sesuai dengan kebutuhannya. Sementara, dapat dikatakan negatif karena kondisi tersebut menyebabkan posisi konsumen menjadi lebih lemah dari pada posisi pelaku usaha yang dapat mengakibatkan kekecewaan dan kerugian. ${ }^{6}$

Karakteristik e-commerce seperti ini konsumen akan menghadapi berbagai persoalan hokum, sedangkan peraturan perlindungan hukum bagi konsumen yang ada sekarang belum mampu melindungi konsumen dalam transaksi $e$ commerce. Selain itu, dalam transaksi e-commerce tidak ada lagi batas negara maka undang-undang perlindungan konsumen masing-masing negara seperti yang dimiliki Indonesia tidak akan cukup membantu, karena e-commerce beroperasi secara lintas batas (borderless). ${ }^{7}$

\section{Rumusan Masalah}

Berdasarkan penjelasan dari latar belakang di atas, maka rumusan masalah pada penulisan ini yaitu bagaimana urgensi pembaharuan hukum perlindungan konsumen Indonesia di era e-commerce?

\section{Tujuan Penelitian}

Adapun tujuan yang ingin dicapai adalah untuk mengetahui urgensi pembaharuan hukum perlindungan konsumen Indonesia di era e-commerce.

\section{Metode Penelitian}

Metode yang digunakan oleh peneliti adalah metode hukum normatif atau yang disebut juga dengan penelitian kepustakaan, di mana penulis menganalisis konsep-konsep dan peraturan hukum yang berkaitan dengan penelitian serta juga menganalisis buku-buku, jurnal-jurnal, dan dokumen-dokumen lain yang

\footnotetext{
${ }^{5}$ Imam Lukito, "Tantangan Hukum dan Peran Pemerintah Dalam Pembangunan E-Commerce", Jurnal Ilmiah Kebijakan Hukum, Edisi No. 3, Vol. 11, Badan Penelitian dan Pengembangan Hukum dan Hak Asasi Manusia, 2017, hlm. 351.

${ }^{6}$ Happy Susanto, Hak-Hak Konsumen Jika Dirugikan, Visi Media, Yogyakarta, 2008, hlm. 3.

${ }^{7}$ Agus Budi, Hukum dan Internet di Indonesia, UII Press, Yogyakarta, 2003, hlm. 63.
} 
dibutuhkan dalam melakukan penelitian. Sumber data yang digunakan adalah sumber data sekunder, meliputi bahan hukum primer, sekunder, dan tersier. Selanjutnya dijelaskan melalui deskriptif. Fokus kajian menelaah dan mengkaji berkaitan dengan pembaharuan hukum perlindungan konsumen Indonesia di era e-commerce.

\section{Hasil Penelitian dan Pembahasan}

\section{Urgensi Pembaharuan Hukum Perlindungan Konsumen Indonesia di Era E- Commerce}

Perkembangan perkonomian dewasa ini telah memacu tumbuhnya sektor produksi dan perdagangan yang dalam kenyataan secara tidak langsung menciptakan kekuatan posisi pelaku usaha di satu sisi dan menempatkan konsumen di sisi yang lain. Sebagian pelaku usaha dalam melakukan kegiatannya acapkali mengabaikan kepentingan konsumen. Mengingat posisinya seperti itu, konsumen sering "terpaksa" menerima suatu produk barang/jasa, meskipun tidak sesuai dengan yang diinginkan. ${ }^{8}$

Kedudukan konsumen dipengaruhi oleh konsep-konsep pemasaran yang berubah dari waktu kewaktu. Pertama, memfokuskan pada produk dan pelaku usaha dengan membuat produk yang baik berdasarkan standar dan nilai internal. Kedua, mngalihkan fokus pemasaran dari produk kepada konsumen. Ketiga, sebagai konsep baru pemasaran, dengan pembaharuan konsep pemasaran menjadi konsep strategi. Konsep strategi pemasaran pada dasarnya merubah fokus pemasaran dari konsumen atau produk kepada konsumen dalam konteks lingkungan eksternal yang lebih luas. ${ }^{9}$

Posisi konsumen dalam masyarakat modern berada dalam posisi yang tidak seimbang dengan pelaku usaha, sehingga konsumen cenderung berada dalam posisi yang lemah. Hal ini didasarkan pada beberapa argumentasi, yaitu: pertama, dalam masyarakat modern, pelaku usaha menawarkan berbagai jenis barang yang diproduksi secara masal. Kedua, banyaknya berbagai jenis barang di pasar yang membuat konsumen sulit untuk memahami berbagai macam produk yang tersedia. Ketiga, metode periklanan modern melakukan disinformasi kepada konsumen daripada memberikan informasi secara objektif. Keempat, sulitnya konsumen memperoleh informasi-informasi yang memadai. Kelima, berkembangnya gagasan paternalism, yaitu terdapat rasa tidak percaya terhadap kemampuan konsumen melindungi dirinya sendiri. ${ }^{10}$

\footnotetext{
${ }^{8}$ Ibid.

9 Abdul Halim Barkatullah, Hak-Hak. Konsumen, Ctk. Kesatu, Nusa Media, Bandung, 2010, hlm. 8.

${ }^{10}$ Ibid., hlm. 9.
} 
Hubungan yang tidak seimbang tersebut membuka peluang bagi pelaku usaha, yang didorong oleh semangat untuk mengeruk keuntungan sebesarbesarnya untuk menyalahgunakan posisinya yang lebih unggul dalam hubungannya dengan konsumen. Penyalahgunaan tersebut hampir selalu membawa kerugian bagi pihak konsumen. ${ }^{11}$ Dalam dunia perdagangan saat ini, transaksi elektronik adalah suatu hal yang tidak dapat dihindarkan. Electronic Commerce (e-commerce) adalah suatu contoh dari kemajuan yang terjadi, dimana transaksi bisnis tidak lagi dilakukan secara konvensional, yang mengharuskan pembeli berinteraksi langsung dengan penjual atau adanya keharusan menggunakan uang tunai. ${ }^{12}$ Praktik transaksi e-commerce banyak menimbulkan permasalahan permasalahan yang cenderung merugikan konsumen dan dalam melakukan transaksi e-commerce. ${ }^{13}$

Dalam transaksi e-commerce diciptakan transaksi bisnis yang lebih praktis tanpa kertas (paperless) dan dalam transaksi e-commerce dapat tidak bertemu secara langsung (face to face) para pihak yang melakukan transaksi, sehingga dapat dikatakan e-commerce menjadi penggerak ekonomi baru dalam bidang teknologi. Selain keuntungan tersebut, aspek negatif dari pengembangan ini adalah berkaitan dengan persoalan keamanan dalam bertransaksi dengan menggunakan media e-commerce. Munculnya bentuk penyelewenganpenyelewengan yang cenderung merugikan konsumen dan menimbulkan berbagai permasalahan hukum dalam melakukan transaksi e-commerce. ${ }^{14}$

Masalah hukum yang menyangkut perlindungan hukum konsumen semakin mendesak dalam hal seorang konsumen melakukan transaksi e-commerce dengan merchant dalam satu negara atau berlainan negara. Di dalam jual beli melalui internet, seringkali terjadi kecurangan. Kecurangan-kecurangan tersebut dapat terjadi yang menyangkut keberadaan pelaku usaha, barang yang dibeli, harga barang, dan pembayaran oleh konsumen. Kecurangan yang menyangkut pelaku usaha, misalnya pelaku usaha (virtual store) yang bersangkutan merupakan toko yang fiktif. ${ }^{15}$ hlm. 6.

${ }^{11}$ Firman Tumantara Endipradja, Hukum Perlindungan Konsumen, Ctk. Kesatu, Setara Press, Malang, 2016,

12 Imam Lukito, Loc. Cit.

13 Abdul Halim Barkatullah, "Urgensi Perlindungan Hak-Hak Konsumen Dalam Transaksi ECommerce", Jurnal Hukum, Edisi No. 2 Vol. 14, Universitas Islam Indonesia, 2007, hlm. 264.

14 Atip Latifulhayat, "Perlindungan Data Pribadi dalam Perdagangan Secara Elektronik (e-Commerce)", Jurnal Hukum Bisnis, Vol. 18 , Maret 2002, hlm. 24.

15 Abdul Halim Barkatullah, Hak-Hak ...., Op. Cit., hlm. 250. 
Secara garis besar, dapat ditemukan beberapa permasalahan yang timbul yang berkenaan dengan hak-hak konsumen dalam transaksi e-commerce, antara lain: 16

1) Konsumen tidak dapat langsung mengidentifikasi, melihat, atau menyentuh barang yang akan dipesan;

2) Ketidakjelasan informasi tentang produk yang ditawarkan dan/atau tidak ada kepastian apakah konsumen telah memperoleh berbagai informasi yang layak diketahui atau yang sepatutnya dibutuhkan untuk mengambil suatu keputusan dalam bertransaksi;

3) Tidak jelasnya status subjek hukum dari pelaku usaha;

4) Tidak ada jaminan keamanan bertransaksi dan privasi serta penjelasan terhadap risiko-risiko yang berkenaan dengan sistem yang digunakan, khususnya dalam hal pembayaran secara elektronik, baik dengan credit card maupun electronic cash;

5) Pembebanan risiko yang tidak berimbang karena umumnya terhadap jual beli di internet pembayaran telah lunas dilakukan di muka oleh konsumen, sedangkan barang belum tentu diterima atau akan menyusul kemudian, karena jaminan yang ada adalah jaminan pengiriman barang bukan penerimaan barang;

6) Transaksi yang bersifat lintas batas negara borderless, menimbulkan pertanyaan mengenai yurisdiksi hukum negara mana yang sepatutnya diberlakukan.

Melihat permasalah hak-hak konsumen dalam transaksi e-commerce di atas dapat dilihat hak-hak konsumen dalam transaksi e-commerce sangat riskan sekali untuk dilanggar dan menempatkan konsumen dalam transaksi $e$-commerce berada dalam posisi tawar yang lemah, apalagi konsumen taransaksi e-commerce yang dilakukan lintas negara. ${ }^{17}$ Apabila transaksi e-commerce tersebut berlangsung di antara pihak-pihak khususnya perorangan yang merupakan penduduk dua negara yang berbeda, maka akan timbul masalah dalam penyelesaian sengketa, apakah dilakukan dengan penerapan hukum negara tergugat atau berdasarkan hukum negara penggugat atau apakah seyogyanya didasarkan kepada negara pelaku usaha atau apakah didasarkan hukum negara dari konsumen. ${ }^{18}$

Masalah yurisdiksi atau tempat di mana terjadinya transaksi, masalah pilihan hukum atau pilihan forum. Transaksi bisnis melalui media net atau telematika tidak menjelaskan tempat di mana transaksi itu terjadi. Hal ini sangat penting secara yuridis, karena berkaitan dengan yurisdiksi pengadilan yang berwenang jika timbul sengketa dan masalah pilihan hukum (choice of law atau applicable law). Oleh karena kebanyakan transaksi e-commerce dilakukan oleh para

\footnotetext{
16 Ibid., hlm. 261.

${ }^{17}$ Ibid.

${ }^{18}$ Ibid., hlm. 264.
} 
pihak yang berada pada yurisdiksi hukum negara yang berbeda, sementara dalam terms and condition pada saat kesepakatan secara online dibuat tidak secara tegas dan jelas menunjuk atau memuat klausul choice of law, maka menjadi persoalan hukum negara atau hakim manakah yang berwenang mengadili, jika dikemudian hari terjadi sengketa. ${ }^{19}$

Perlindungan konsumen di Indonesia diatur dalam Undang-Undang Nomor 8 Tahun 1999 tentang Perlindungan Konsumen atau yang sering dikenal sebagai UU PK. Pasal 4 UU PK telah mengatur hak-hak konsumen yang meliputi:

1) Hak atas kenyamanan, keamanan, dan keselamatan dalam konsumsi barang dan/atau jasa.

2) Hak untuk memilih barang dan/atau jasa serta mendapatkan barang dan/atau jasa tersebut sesuai dengan nilai tukar dan kondisi serta jaminan yang dijanjikan.

3) Hak atas informasi yang benar, jelas, dan jujur mengenai kondisi dan jaminan barang dan/atau jasa.

4) Hak untuk didengar pendapat dan keluhannya atas barang dan/atau jasa yang digunakan.

5) Hak untuk mendapatkan advokasi, perlindungan, dan upaya penyelesaian sengketa perlindungan konsumen secara patut.

6) Hak untuk mendapatkan pembinaan dan pendidikan konsumen.

7) Hak untuk diperlakukan atau dilayani secara benar dan jujur serta tidak diskriminatif.

8) Hak untuk mendapatkan kompensasi,ganti rugi dan/atau penggantian, apabila barang dan/atau jasa yang diterima tidak sesuai dengan perjanjian atau tidak sebagaimana mestinya.

9) Hak-hak yang diatur dalam ketentuan peraturan perundang-undangan lainnya.

Apabila diperhatikan dengan lebih seksama, hak-hak konsumen sebagaimana disebutkan dalam UU PK terkesan hanya terbatas pada aktivitas jual-beli yang sifatnya konvensional. Di samping itu, perlindungan pun hanya difokuskan pada sisi konsumen dan produk (barang dan jasa) yang diperjualbelikan. Sedangkan perlindungan dari sisi produsen/pelaku usaha, seperti informasi tentang identitas dan alamat/tempat bisnis pelaku usaha/produsen, baik kantor cabang maupun kantor utamanya serta jaminan kerahasiaan data-data milik konsumen diabaikan. Padahal hal-hal tersebut sangat penting diatur untuk keamanan konsumen dalam bertransaksi. ${ }^{20}$

19 Abdul Halim Barkatullah, "Urgensi Perlindungan Hak-Hak Konsumen dalam Transaksi E-Commerce", dikutip dari Nindyo Pramono, "Revolusi Dunia Bisnis Indonesia Melalui E-Commerce dan E-Business: Bagaimana Solusi Hukumnya", Makalah Disampaikan dalam Seminar Nasional Peluang E-Bisnis serta Kesiapan Hukumnya di Indonesia, UKDW Yogyakarta, Hotel Ambarukmo, Yogyakarta, 14 April 2001, hlm. 3.

${ }^{20}$ Rina Aringintri Moksi. "Perlindungan Konsumen Dalam Transaksi Jual Beli Secara E-Commerce." Tesis, Pasca Sarjana Universitas Diponegoro, 2006, hlm. 78. 
Begitu pula apabila dilihat Ketentuan Umum Pasal 1 Angka 6 UU PK, pengertian promosi tidak disebutkan secara jelas media apa yang dipakai dalam melakukan promosi ini apakah termasuk di dalamnya media internet atau tidak. Pasal 1 angka 6 UU PK, menyebutkan:

"Promosi adalah kegiatan pengenalan atau penyebarluasan informasi suatu barang dan / atau jasa yang akan dan sedang diperdagangkan". Oleh karena itu beranjak dari masih banyaknya materi-materi yang belum diatur maka sudah saatnya apabila materi-materi tersebut dipertimbangkan untuk dimuat dalam ketentuan yang baru. ${ }^{21}$

Pasal 1 ayat (1) UU PK menjelasakan bahwa perlindungan konsumen adalah segala upaya yang menjamin adanya kepastian hukum untuk memberi perlindungan kepada konsumen. Berkaitan dengan perlindungan konsumen, Undang-Undang Nomor 19 Tahun 2016 tentang Perubahan Atas Nomor UndangUndang 11 Tahun 2008 tentang Informasi dan Transaksi Elektronik yang selanjutnya disebut UU ITE mengatur bebrapa ketentuan yang merupakan bentuk perlindungan hukum kepada konsumen pengguna transaksi e-commerce. Bentuk perlindungan hukum tersebut meliputi, sebagai berikut:

\section{Ketentuan tentang yurisdiksi}

Pasal 18 UU ITE merupakan pasal yang mengatur tentang yurisdiksi transaksi elektronik. Pasal ini terdiri dari 5 ayat yang berbunyi sebagai berikut:

1) Transaksi Elektronik yang dituangkan ke dalam kontrak elektronik mengikat para pihak.

2) Para pihak memiliki kewenangan untuk memilih hukum yang berlaku bagi Transaksi Elektronik internasional yang dibuatnya.

3) Jika para pihak tidak melakukan pilihan hukum dalam transaksi Elektronik Internasional, hukum yang berlaku didasarkan pada asas Hukum Perdata Internasional.

4) Para pihak memiliki kewenangan untuk menetapkan forum pengadilan, arbitrase, atau lembaga penyelesaian sengketa alternatif lainnya yang berwenang menangani sengketa yang mungkin timbul dari transaksi Elektronik internasional yang dibuatnya.

5) Jika para pihak tidak melakukan pilihan forum sebagaimana dimaksud pada ayat (4), penetapan kewenangan pengadilan, arbitrase, atau lembaga penyelesaian sengketa alternatif lainnya yang berwenang menangani sengketa yang mungkin timbul dari transaksi tersebut, didasarkan pada asas hukum perdata internasional.

Permasalahan dari pasal ini adalah transaksi bisnis melalui media internet atau telematika tidak menjelaskan tempat di mana transaksi itu terjadi. Padahal 
hal ini seharusnya diatur secara yuridis karena berkaitan dengan yurisdiksi pengadilan yang berwenang jika timbul sengketa. Kebanyakan transaksi $e$ commerce dilakukan oleh para pihak yang berada pada yurisdiksi hukum negara yang berbeda, sementara dalam terms and condition pada saat kesepakatan secara online dibuat tidak secara tegas. Nyatanya ini menunjukkan secara jelas atau seharusnya memuat klausul choice of law agar ketika terjadi persoalan hukum negara, hakim dapat menentukan kewenangannya untuk mengadili, jika di kemudian hari terjadi sengketa. ${ }^{22}$

Apabila dilihat dari hubungan subyek atau pelakunya, jenis transaksi $E$ Commerce dapat dibagi menjadi 3, yaitu:

1) Business to business (B2B), merupakan transaksi elektronik yang dilakukan antar pelaku usaha. Contoh bisnis e-commerce yang menerapkan transaksi ini adalah bizzy.co.id, ralali.com. ${ }^{23}$

2) Business to Consumer (B2C), merupakan suatu transaksi elektronik yang dilakukan antara pelaku usaha dan konsumen. ${ }^{24}$ Contoh bisnis e-commerce yang menerapkan transaksi ini adalah Amazon.com, ebay.com.

3) Consumer to Consumer (C2C) merupakan transaksi bisnis secara elektronik yang dilakukan antar konsumen. ${ }^{25}$

Apabila transaksi elektronik dilihat dari hubungan subyek atau pelakunya, Pasal 18 UU ITE hanya dapat diterapkan kepada bentuk transaksi C2C dan tidak pada transaksi B2B dan B2C. Hal ini dikarenakan dalam transaksi B2B dan B2C, penjual diwakili oleh sistem yang melayani pembeli secara online melalui jaringan komputer di mana dalam terms and condition pada saat kesepakatan secara online dibuat, tidak secara tegas dan jelas menunjuk atau memuat klausul choice of law, maka menjadi persoalan hukum negara atau hakim manakah yang berwenang mengadili, jika di kemudian hari terjadi sengketa. Selain itu, transaksi bisnis melalui media net atau telematika juga tidak menjelaskan tempat di mana transaksi itu terjadi. ${ }^{26}$ sehingga perlindungan hukum bagi konsumen harus dilakukan dengan pendekatan Internasional melalui harmonisasi hukum.

\section{Ketentuan tentang itikad baik dalam transaksi}

1) Pasal 9 UU ITE mengatur bahwa pelaku usaha yang menawarkan produk melalui Sistem Elektronik harus menyediakan informasi yang lengkap dan

22 Abdul Halim Barkatullah, Hak-Hak ...., Loc. Cit.

${ }^{23}$ Imam Lukito, Op. Cit., hlm. 354.

${ }^{24}$ Ambar Wariati dan Nani Irma Susanti, “E-Commerce Dalam Perspektif Perlindungan Konsumen”, Jurnal Ekonomi \& Bisnis, No. 2 Vol. 1, 2014, hlm. 5.

25 Ibid.

${ }^{26}$ Abdul Halim Barkatullah, Hak-Hak ...., Loc. Cit. 
benar berkaitan dengan syarat kontrak, produsen, dan produk yang ditawarkan.

2) Pasal 17 ayat (2) UU ITE mengatur mengenai kewajiban para pihak untuk beritikad baik dalam melakukan transaksi elektronik melalui pertukaran informasi elektronik.

Pasal 9 dan Pasal 17 ayat (2) UU ITE merupakan norma agendi yang mana memiliki pengertian hanya mengatur perbuatan saja tanpa diatur bagaimana kalau ketentuan tersebut dilanggar, baik secara perdata maupun pidana. Mengenai ketentuan pidana, UU ITE mengaturnya secara khusus dalam BAB XI, dari ketentuan Pasal 45 sampai Pasal 52 dalam BAB XI UU ITE, tidak ada yang mengatur tentang sanksi dari dilanggarnya Pasal 9 maupun Pasal 17 ayat (2), sehingga kedua pasal tersebut menurut penulis lemah dan tidak dapat ditegakan.

\section{Ketentuan tentang perlindungan konsumen dari sudut pandang pidana}

BAB VII UU ITE adalah BAB yang mengatur perbuatan yang dilarang, di mana dalam $B A B$ ini perbuatan yag dilarang diatur mulai dari Pasal 27 sampai dengan Pasal 37, sementara ketentuan pidana dari perbuatan-perbuatan yang dilarang ini diatur dalam BAB XI tentang ketentuan pidana. Dari 10 Pasal tersebut hanya terdapat 1 pasal yang memberikan perlindungan kepada konsumen yaitu dari perbuatan penyebaran berita bohong dan pnyesatan melalui internet yaitu padal Pasal 28 ayat (1) UU ITE. Sementara pasal lainnya mengatur tentang perbuatan yang dilarang lainnya yaitu:

1) Pornografi di internet (Pasasl 27 ayat (1))

2) Perjudian di internet (Pasal 27 ayat (2))

3) Penghinaan/pencemaran nama baik di internet (Pasal 27 ayat (3) dan Pasal 29)

4) Pemerasan dan/atau pengancaman melalui internet (Pasal 27 ayat (4))

5) Profokasi melalui internet (Pasal 28 ayat (2))

6) Hacking (Pasal 30)

7) Intersepsi atau penyadapan (Pasal 31)

8) Defacing (Pasal 32 ayat (1) dan ayat (3))

9) Pencurian melalui internet (Pasal 32 ayat (2))

10) Pengangguan melalui internet (Pasal 33)

11) Fasilitator cybercrime (Pasal 34)

12) Plagiat (pembajakan) di internet (Pasal 35)

13) Cybercrime yang menimbulkan kerugian terhadap orang lain (Pasal 36)

14) Cybercrime Lintas Yurisdiksi Indonesia (Pasal 37)

Pasal 28 ayat (1) berbunyi:

"Setiap Orang dengan sengaja dan tanpa hak menyebarkan berita bohong dan menyesatkan yang mengakibatkan kerugian konsumen dalam Transaksi Elektronik." 
Kendatipun secara pidana konsumen dilindugi dari perbuatan penyebaran berita bohong dan penyesatan melalui internet yang merugikan konsumen, hal tersebut tidak memberikan kompensasi apapun kepada konsumen yang dirugikannya. Karena bentuk sanksi yang diberikan berdasarkan UU ITE adalah berupa pidana kurungan atau pidana penjara dan/atau pidana denda.

Berdasarkan pernyataan di atas, adanya karakteristik e-commerce seperti ini konsumen akan menghadapi berbagai persoalan hukum dan peraturan perlindungan hukum bagi konsumen yang ada sekarang belum mampu melindungi konsumen dalam hal yang berkaitan dengan transaksi e-commerce di Indonesia. Dalam transaksi e-commerce tidak ada lagi batas negara maka undangundang perlindungan konsumen masing-masing negara seperti yang dimiliki Indonesia tidak akan cukup membantu, karena e-commerce beroperasi secara lintas batas (borderless). Dalam kaitan ini, perlindungan hukum bagi konsumen harus dilakukan dengan pendekatan internasional melalui harmonisasi hukum dan kerjasama institusi-institusi penegak hukum. ${ }^{27}$

Menurut Mochtar Kusumaatmadja, hukum mempunyai kekuasaan untuk melindungi dan mengayomi seluruh lapisan masyararkat, sehingga tujuan hukum dapat tercapai dalam mewujudkan keadilan sosial bagi seluruh rakyat Indonesia. Selain itu, hukum berfungsi sebagai sarana penunjang perkembangan pembangunan melalui peningkatan dan penyempurnaan pembinaan tata hukum nasional dengan mengadakan pembaruan, kodifikasi, dan unifikasi hukum di bidang-bidang tertentu dengan jalan memerhatikan kesadaran hukum dalam masyarakat. ${ }^{28}$

Masalah pemilihan bidang hukum mana yang hendak dikembangkan dan untuk menetapkan bidang hukum mana yang sebaiknya harus dikembangkan dapat dipakai berbagai macam kriteria yaitu: ${ }^{29}$

1) Keperluan yang mendesak (urgenned).

2) Perubahan yang pokok (fundamental change) yaitu perubahan (melalui perundang-undangan) diperlukan karena pertimbangan-pertimbangann politis, ekonomi, dan/atau sosial. ${ }^{30}$

Kriteria keperluan yang mendesak atau kriteria poin 1 dapat dilihat bahwa baik payung hukum perlindungan konsumen Indonesia yaitu Undang-Undang Nomor 8 Tahun 1999 dan Undang-Undang Nomor 11 Tahun 2008 jo. UndangUndang Nomor 19 Tahun 2016 tentang Informasi dan Transaksi Elektronik

\footnotetext{
${ }^{27}$ Agus Budi, Op. Cit.

28 Mochtar Kusumaatmadja, Konsep-Konsep Hukum Dalam Pembangunan, Alumni, Bandung, 2006, hlm. 85-86. hlm. 100.

${ }^{29}$ Budi Suharianto, Tindak Pidana Teknologi Informasi (Cybercrime), Ctk. Ketiga, Rajawali Pers, Jakarta, 2014,

${ }^{30}$ Mochtar Kusumaatmadja, Pembinaan Hukum..., Op. Cit., hlm. 12-13.
} 
sebagai Undang-Undang pendukung perlindungan konsumen tidak memadai untuk menyelesaikan permasalahan-permasalahan yang muncul.

Permasalahan yang timbul yang berkenaan dengan hak-hak konsumen dalam transaksi e-commerce, antara lain: konsumen tidak dapat langsung mengidentifikasi, melihat, atau menyentuh barang yang akan dipesan, ketidakjelasan informasi tentang produk yang ditawarkan dan/atau tidak ada kepastian apakah konsumen telah memperoleh berbagai informasi yang layak diketahui, atau yang sepatutnya dibutuhkan untuk mengambil suatu keputusan dalam bertransaksi. Tidak jelasnya status subjek hukum, dari pelaku usaha, tidak ada jaminan keamanan bertransaksi, dan privasi serta penjelasan terhadap risikorisiko yang berkenaan dengan sistem yang digunakan, khususnya dalam hal pembayaran secara elektronik, baik dengan credit card maupun electronic cash.

Pembebanan risiko yang tidak berimbang, karena umumnya terhadap jual beli di internet, pembayaran telah lunas dilakukan di muka oleh konsumen. Sedangkan barang belum tentu diterima atau akan menyusul kemudian, karena jaminan yang ada adalah jaminan pengiriman barang bukan penerimaan barang. Transaksi yang bersifat lintas batas negara borderless menimbulkan pertanyaan mengenai yurisdiksi hukum negara mana yang sepatutnya diberlakukan. ${ }^{31}$

Apabila diperhatikan dengan lebih seksama, hak-hak konsumen sebagaimana disebutkan dalam UU PK terkesan hanya terbatas pada aktivitas jual-beli yang sifatnya konvensional. Di samping itu, perlindungan pun hanya difokuskan pada sisi konsumen dan produk (barang dan jasa) yang diperjualbelikan. Sedangkan perlindungan dari sisi produsen/pelaku usaha, seperti informasi tentang identitas dan alamat/tempat bisnis pelaku usaha/produsen, baik kantor cabang maupun kantor utamanya serta jaminan kerahasiaan data-data milik konsumen diabaikan. ${ }^{32}$

Masalah hukum yang menyangkut perlindungan hukum konsumen semakin mendesak dalam hal seorang konsumen melakukan transaksi e-commerce dengan merchant dalam satu negara atau berlainan negara. Masalah yurisdiksi atau tempat di mana terjadinya transaksi, masalah pilihan hukum atau pilihan forum. Transaksi bisnis melalui media net atau telematika tidak menjelaskan tempat di mana transaksi itu terjadi. Hal ini sangat penting secara yuridis, karena berkaitan dengan yurisdiksi pengadilan yang berwenang jika timbul sengketa dan masalah pilihan hukum (choice of law atau applicable law). Oleh karena kebanyakan transaksi e-commerce dilakukan oleh para pihak yang berada pada yurisdiksi hukum negara yang berbeda, sementara dalam terms and condition pada

31 Abdul Halim Barkatullah, Op. Cit.

32 Rina Aringintri Moksi, Op. Cit. 
saat kesepakatan secara online dibuat tidak secara tegas dan jelas menunjuk atau memuat klausul choice of law, maka menjadi persoalan hukum negara atau hakim manakah yang berwenang mengadili, jika di kemudian hari terjadi sengketa. ${ }^{33}$

Begitu juga dengan UU ITE sebagai aturan pendukung perlindungan konsumen di Indonesia. Dalam hal ini, untuk mengatasi permasalahan transaksi elektronik belum memadai untuk mengatasi permasalahan-permasalahan perlindungan konsumen di era modern. Dengan karakteristik e-commerce seperti ini konsumen akan menghadapi berbagai persoalan hukum dan peraturan perlindungan hukum bagi konsumen yang ada sekarang belum mampu melindungi konsumen dalam transaksi e-commerce lintas negara di Indonesia.

Unsur perubahan yang pokok atau krtiteria poin 2 dapat dilihat dari pertimbangan dari sudut pandang sosial. Kegiatan bisnis dilakukan manusia di desa-kota-dunia, anak-anak hingga dewasa, miskin-kaya, pendidikan rendahtinggi, formal-informal, yang kesemuanya bertujuan untuk mencari keuntungan yang tidak ada lain diperoleh dari hasil penjualan barang/jasa kepada konsumen. Disadari atau tidak, setiap manusia adalah konsumen. Semua pelaku usaha adalah konsumen, sebaliknya tidak semua konsumen adalah pelaku usaha, sehingga masalah-masalah yang dihadapi oleh konsumen adalah menyangkut semua lapisan dan golongan masyarakat yang perlu mendapatkan perhatian.

Posisi konsumen dalam masyarakat modern berada dalam posisi yang tidak seimbang dengan pelaku usaha dan konsumen cenderung berada dalam posisi yang lemah. Hal ini didasarkan pada beberapa argumentasi, yaitu dalam masyarakat modern, pelaku usaha menawarkan berbagai jenis barang yang diproduksi secara masal. Banyaknya berbagai jenis barang di pasar membuat konsumen sulit untuk memahami berbagai macam produk yang tersedia. Metode periklanan modern melakukan disinformasi kepada konsumen daripada memberikan informasi secara objektif sehingga sulitnya konsumen memahami informasi-informasi yang memadai. ${ }^{34}$ Maka apabila dilihat dari sudut pandang sosial pembaharuan hukum perlindungan konsumen Indonesia sangatlah dibutuhkan adanya pembaruan hukum terkait perlindungan konsumen. Hal ini dilakukan untuk menciptakan ketertiban dan keadilan dalam melindungi kepentingan-kepentingan konsumen, terutama terhadap masyarakat yang posisinya lemah.

\section{Penutup}

Urgensi pembaharuan Undang-Undang Perlindungan Konsumen Indonesia di era e-commerce dapat dinilai berdasarkan 2 kriteria yaitu kebutuhan yang

\footnotetext{
33 Abdul Halim Barkatullah, Op. Cit.

${ }^{34}$ Abdul Halim Barkatullah, Hak-Hak Konsumen..., Op. Cit, hlm. 8.
} 
mendesak dan perubahan yang pokok dengan pertimbangan politis, ekonomi, dan/atau sosial. Berdasarkan analisis penulis Undang-Undang Nomor 8 Tahun 1999 tentang Perlindungan Konsumen yang berlaku sekarang tidak memadai untuk memecahkan masalah-masalah yang ditimbulkan akibat adanya perkembangan zaman yakni dengan lahirnya transaksi e-commerce. Bahkan Undang-Undang Nomor 11 Tahun 2008 jo. Undang-Undang Nomor 19 Tahun 2019 tentang Informasi dan Transaksi Elektronik yang menjadi pendukung Undang-Undang Perlindungan Konsumen juga belum memadai untuk mendukung perlindungan konsumen dari sisi transaksi e-commerce, sehingga Undang-Undang Perlindungan Konsumen menjadi hal penting untuk diperbaharui supaya dapat memberikan perlindungan kepada konsumen yang dalam masyarakat modern berada dalam posisi yang tidak seimbang dengan pelaku usaha dan konsumen cenderung berada dalam posisi yang lemah.

\section{Daftar Pustaka}

\section{Buku}

Adolf, Huala, Hukum Perdagangan Internasional, PT. Raja Grafindo Persada, Jakarta, 2005.

Barkatullah, Abdul Halim, Hak-Hak Konsumen, Ctk. Kesatu, Nusa Media, Bandung, 2010.

Budi, Agus, Hukum dan Internet Di Indonesia, UII Press, Yogyakarta, 2003.

Endipradja, Firman Tumantara, Hukum Perlindungan Konsumen, Ctk. Kesatu, Setara Press, Malang, 2016.

Kusumaatmadja, Mochtar, Konsep-Konsep Hukum dalam Pembangunan, Alumni, Bandung, 2006.

Shidarta, Hukum Perlindungan Konsumen, PT Grasindo, Jakarta, 2000.

Suharianto, Budi, Tindak Pidana Teknologi Informasi (Cybercrime), Ctk. Ketiga, Rajawali Pers, Jakarta, 2014.

Susanto, Happy, Hak-Hak Konsumen Jika Dirugikan, Visi Media, Yogyakarta, 2008.

\section{Hasil Penelitian/Tugas Akhir}

Moksi, Rina Aringintri, "Perlindungan Konsumen Dalam Transaksi Jual Beli Secara E-Commerce." Tesis, Pasca Sarjana Universitas Diponegoro, 2006.

\section{Artikel Jurnal}

Ambar Wariati dan Nani irma Susanti, "E-Commerce Dalam Perspektif Perlindungan Konsumen", Jurnal Ekonomi \& Bisnis, No. 2, Vol. 1, 2014.

Arsyad Sanusi, Efektivitas UU ITE dalam Pengaturan Perdagangan Elektronik (ECommerce), Jurnal Hukum Bisnis, 29 (1), 2010.

Atip Latifulhayat, "Perlindungan Data Pribadi dalam Perdagangan Secara Elektronik (e-Commerce)", Jurnal Hukum Bisnis, Vol. 18 , Maret 2002. 
Imam Lukito, "Tantangan Hukum dan Peran Pemerintah Dalam Pembangunan E-Commerce", Jurnal Ilmiah Kebijakan Hukum, Edisi No. 3 Vol. 11, Badan Penelitian dan Pengembangan Hukum dan Hak Asasi Manusia, 2017.

Michael S. Barr and Reuven S. Avi-Yonah, "Globalization, Law, and Development", Michigan Journal of International Law, Vol. 26: 1, University of Michigan Law School, 2004.

\section{Peraturan Perundang-Undangan}

Undang-Undang Nomor 8 Tahun 1999 tentang Perlindungan Konsumen Undang-Undang Nomor 11 Tahun 2008 jo. Undang-Undang Nomor 19 Tahun 2019 tentang Informasi dan Transaksi Elektronik 